\title{
Marching is for soldiers: Russian-born Buriat children in a Chinese bilingual school
}

Valerie Sartor

Correspondence:

vallerina57@gmail.com

Department of English Philology

Division of the Eurasian Linguistic

Institute, Irkutsk State Linguistic

University 8 Lenin Street, Irkutsk

Russian Federation 664025, Russia

\begin{abstract}
This ethnographic study examines the educational struggles of Russian-born Buriat Mongolian children studying in China at a Mongolian/Mandarin school, by emphasizing conflicting educational paradigms between the Russian and Chinese systems. Educational practices are compared. Standardized assessment, teachercentered classrooms, and group- oriented values, all reflected Han-Chinese ideology, but conflicted with Russian educational norms and Russian/Buriat values, causing young Buriat students to resist.
\end{abstract}

\section{Introduction}

In early 2005 I moved to Hohhot, Inner Mongolia, China, to teach college-level English. As a multilingual American, I speak English, Russian and Mandarin. During my first two years in Hohhot, I befriended many Russian-born Buriats, all devout followers of the Dalai Lama. Russian was our common language. We bathed, ate, shopped, prayed, and travelled together. For the next three years (2005-2008) I visited, lived, and traveled with Buriat families around North China, Outer Mongolia, and Russian Buriatia. Our friendship remains ongoing; during the academic year 2014-2015, I resided in Siberia as a Fulbright exchange scholar, socializing with old Buriat friends and families, and making new acquaintances. Over my years of ongoing interaction with members of this Buriat community, I learned why these people periodically migrated from Russia to China, and why they brought their children with them.

"We came to Hohhot because of a Chinese-born Buriat man, Bata," said Erzhena, a Buriat mother (all names are pseudonyms), adding: "I want my sons to become Mongolian doctors." Bata had met Erzhena when he traveled to Ulan Ude on business ten years prior. His family held Chinese citizenship because of the 1920s Buriat diaspora; Bata's grandparents, along with a colony of approximately 8,000 fleeing Buriats, had settled in the northern grasslands of Hulunbeir, Inner Mongolia, China, to escape the ravages of the Russian Civil War (Schwartz 1968). Bata told Erzhena and others about the educational resources that existed in Chinese Inner Mongolia. He described a bilingual school for Mongolians, and a medical institute, ${ }^{1}$ which offered a fusion of traditional Tibetan, Mongolian, and Chinese medical practices. Buriats, being Yellow Hat Buddhists (followers of the Dalai Lama), felt that giving their children this honorable profession - a doctor being also a spiritual healer for Buddhists (Balzar 2011) - was an ideal educational opportunity (Fig. 1). 


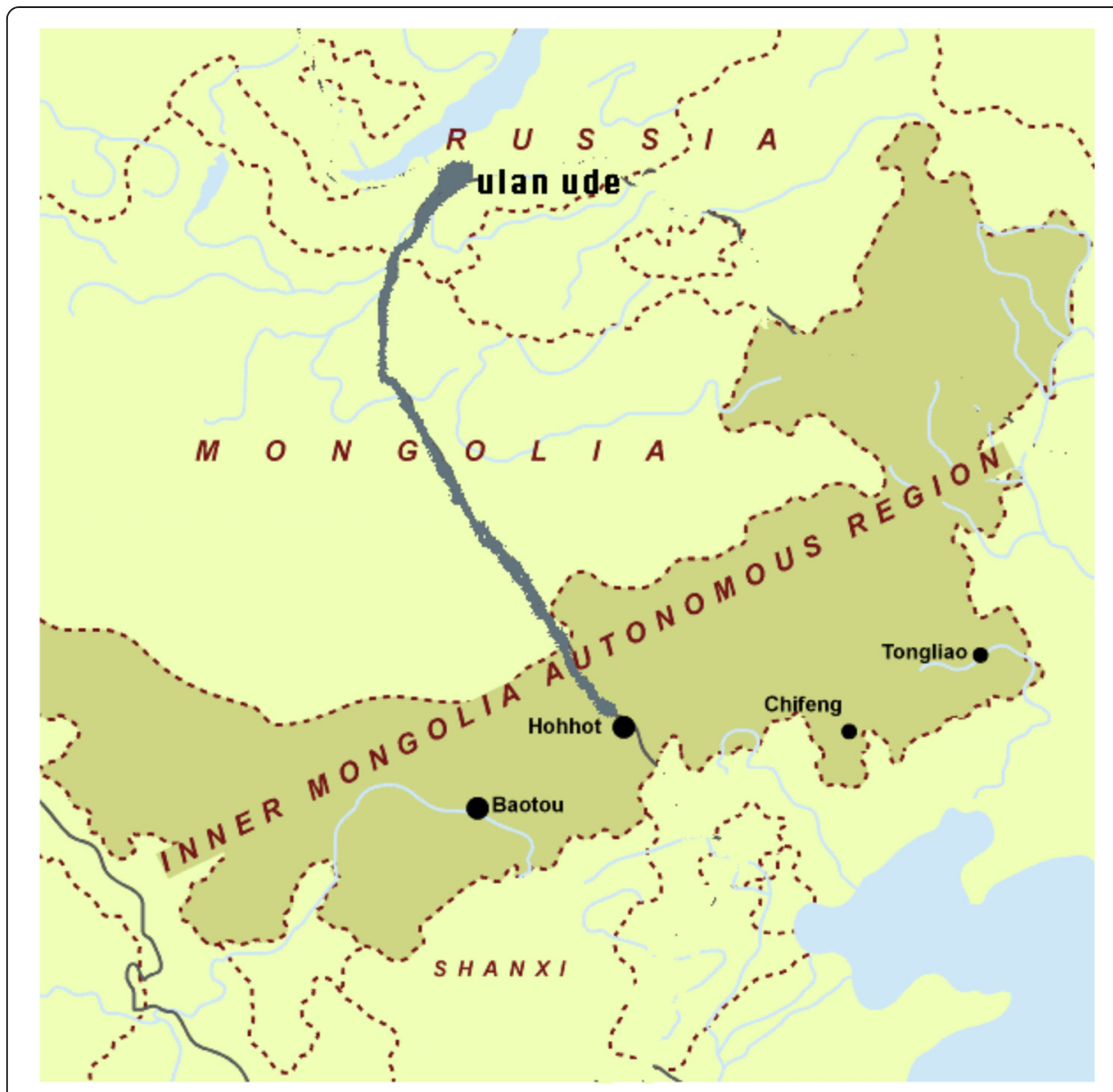

Fig. 1 Migration route

When families trekked to Hohhot, Bata and his extended family, in keeping with traditional Buddhist values, helped them for no gain, monetary or otherwise.

My cordial, pre-established relationship with the Buriat community in Hohhot and their longstanding connections with the Chinese bilingual school resulted in my smooth entry into the school research site, as well as access to diverse participants. For me, fieldwork represents more than geographical location; rather, it consists of complex and ongoing obligations and relations between the researcher and the researched (Ross 2000). My work aims not only to link to other studies of this kind, but also to aid young Buriats in understanding the complex historical and political forces impacting their educational dreams and goals.

\section{Statement of the problem}

This educational research is unique, as these indigenous Buriat youth under consideration have experienced ideological pressures at school from two hegemonic cultures: the ethnic Russian population in the Russian Federation, and the Han Chinese culture in Inner Mongolia, China. In both countries the Buriats are considered as minority peoples, outnumbered by members of the dominant culture, and subjected to the dominant culture's educational and other socialization practices. Using sociocultural theory, Bakhtin (1973, 1981), and Phillips' (1983) participant structures, this article contrasts 
and analyzes four young Buriats' views about Chinese versus Russian school norms. Also, this work illustrates how the Buriat, like other non-mainstream peoples subjected to dominant cultures, may, to some degree, internalize hegemonic norms and educational values.

Stevan Harrell (2013) is a well-known expert of ethnic relations in China in regard to what officials label as their "minorities." Some of his students have studied Inner Mongolians; Borchigud (1995), for example, examined the effects of historical and political circumstances regarding education on Inner Mongolian identity. Bao (1994), to analyze ethnic identity, conducted interviews at schools in Inner Mongolia. Likewise, Gerald Postiglione (1999), as well as Julia Kwong and Hong Xiao (1989) have also examined minority schooling in China, while Judith Liu, Heidi Ross and Donald Kelly (2000) have explored and encouraged significant ethnographic studies of education in China. Yet few scholars have gained access to minority classrooms in China. Wang Yang Xia (2013), however, gained access to study the politics of education among the Hui People in China. My work links with these scholars, while adding a new factor: What are the experiences for Indigenous nonChinese students, young Russian born Buriat Mongolians, who migrate to China seeking education and opportunities in Inner Mongolia? How do they react to Chinese school socialization and how does this socialization differ from what they experienced at home and at school in Buriatia, Russian Federation?

\section{Theoretical framework}

A sociocultural framework encompasses this language socialization research, by integrating ethnographic methods to illustrate social, cultural and ideological interpretations of semiotic forms and practices that novices encounter as they engage with others (Ochs and Schieffelin 2011). As meaning, culture, and identity are social constructs, I also use Bakhtin (1981), who felt that we all need the presence of other(s) to define our own experiences, and to define our self and our reality. His ideas on dialogism repeatedly emphasized how people create themselves in relation to others. Along with Bakhtin, my work is grounded in language socialization theory, which offers insight into indigenous learning styles (Romero-Little 2010). Educators can gain awareness regarding culturally diverse ways of teaching and learning languages (Heath 1983; Ochs 1998). This, in turn, supports equal educational opportunities to all youth.

When children start school they rely on the ways they have learned to learn from their own culture and home community (Romero 2003). Indigenous children may have language behaviors and communicative practices that are expected at home, but which differ from those they encounter in the dominant culture of the school (Phillips 1983). Such disconnects have implications for educational practices (Crago et al., 1993; Heath 1983; Phillips 1983). Despite sharing a common language, teachers who are unfamiliar with a child's community of practice may encounter difficulties and misunderstandings in the classroom (Heath 1983; McCarty et al. 2009). If such children's communicative practices are ignored or treated negatively at school, and if children (and their parents) are not explicitly informed concerning practices of the school's culture, they may have great difficulty in succeeding as students (Fordham 1996; Valdés 2001; Wang 2013).

A critical component also supports my theoretical framework, as schools can serve as vehicles to support hegemonic state norms (Gramsci 1971). To promote social justice, 
the relationship between the wider ethnolinguistic dynamics of school, community, region, and nation must be correlated with what goes on in class, as schools are key spaces for the production, reproduction, and legitimation of the social order (Heller and Jones 2001). Schools require attendance; they serve as places where young people learn appropriate linguistic and behavioral norms, cultural and official rules, as well as knowledge. Schools act as powerful participants in socializing children to accept statelicensed ideologies (Bourdieu and Passeron 1977).

This article first offers sociocultural background regarding the Mongolians. Then I illustrate and compare aspects of Han Chinese educational ideology in relation to postSoviet Russian educational practices regarding workload, structure, patriotism, and assessment. Next, via ethnographic methods, I then examine some of the complexities and tensions young Buriat students from Buriatia, Russian Federation, encountered at the research site, a Chinese bilingual combined primary/secondary school in Hohhot, Inner Mongolia. Base research included socialization practices at home to understand any contrast between home and school, but my main focus was on school practices.

\section{Sociocultural background: indigenous people in inner Asia}

The social, economic, and political position for those who call themselves Mongolians has changed significantly over time (Sneath 2010). Most contemporary Mongolians still live on their indigenous ancestral homelands, but for centuries these grasslands, deserts, and steppes have been carved up, disputed, violated, and invaded by outsiders, e.g. Chinese and Russians. Unlike in the USA, however, these invaders did not create reservations, but rather autonomous republics and regions, which were often overrun demographically by the dominant intruders. With the breakup of the former USSR in 1990 and the economic restructuring of China in the 1980s, Chinese authorities and Russian Federation leaders remain concerned with keeping "their" borderland indigenous Mongolian groups peacefully inside their political ken. Significantly, this balancing act is a double edged sword: powerful countries such as the People's Republic of China (hereafter China) and the Russian Federation (hereafter Russia) wish to appear supportive of diversity and multiculturalism by supporting indigenous languages and bilingual education, but they also want indigenous peoples to assimilate and become homogenous, loyal citizens of the state (Han 2011). This assimilative/diversity paradigm somewhat reflects Western models for indigenous peoples in the USA (Cummins 2000), and elsewhere (Paulston 1994), as well as other non-western countries (Meyer and Alvarado 2010). As little research on indigenous educational practices has been conducted in China (Tsung 2009), this school site in Chinese Mongolia offers a unique sociocultural and sociohistorical ethnographic study addressing language education for multilingual nonmainstream Buriat Mongolian youth.

Most Americans think of Mongols (or Mongolians) when they hear the name of Genghis Khan. His grandson, Kubulai Khan, established the Chinese Yuan Dynasty (1271-1368), but Mongolian power had crumbled by the end of the 14th century (Weatherford 2004). By the end of the 17th century, the Chinese (Qing Dynasty) controlled what we now know as Outer and Inner Mongolia. In 1911, however, Outer Mongolia regained independence from China. Later, in 1924, these lands were overrun and colonized by Soviet leadership (Schwartz 1968), and remained a satellite colony of the former USSR until 1991. Currently, Outer Mongolia stands as an independent 
but economically struggling nation (Rossabi 2005), while Inner Mongolia since 1947 has stood as a so-called autonomous region strongly affiliated with the Chinese People's Republic (Bulag 1998). Inner Mongolia has gained more economic prosperity than Outer Mongolia, but some Inner Mongolians have lost their language and traditions (Bulag 2002; Sneath 2010).

The Buriat, an indigenous Mongolian people, have lived in Siberian areas around Lake Baikal for some 300,000 years and claim this area as their sacred, ancestral homeland (Forsyth 1992). Buriat lands were repeatedly invaded from the 1700s, first by colonizing Russians, and later in the early 20th century by Soviet leadership, who turned Buriat lands into an autonomous minority region of the USSR. In 1993, after the collapse of the USSR in late 1991, for economic reasons, Buriats realigned with the newly formed Russian Federation (Montgomery 2005), where they are considered the most Russified of all Siberian indigenous people (Khilkhanova and Khilkhanov 2004). With the economic as well as political collapse of the USSR in the early 1990s, Buriats, like others living on post-Soviet lands (Humphrey 2002), are struggling to regain an economic foundation for survival (Humphrey 1996), while also revitalizing their culture and spiritual beliefs (Balzer 2011). Buriatia remains poorer than most Russian regions. Local people in Buriatia have told me that they are resigned to economic crises. Some Buriats fear President Putin's increasing desire to control Siberian natural resources ${ }^{2}$ (Graber 2012). Certainly, Soviet/Russian policies have harmed Buriat linguistic vitality (Khilkhanova and Khilkhanov 2004) and decreased the size of Buriat homelands (Graber 2012).

Buriats differ from the Inner and Outer Mongolians not only linguistically, but also culturally, as their homelands are more forested and full of lakes, including Lake Baikal, the deepest freshwater lake in the world. Geography has made Buriat food and dress distinct from steppe and grassland Mongols. Russian influences have also impacted their language, diet, and livelihood (Humphrey 1996). Other Mongols may consider Buriats as "Russians;" while Buriats consider Outer Mongolians as the 'pure, poor, wilder brothers' (Graber 2012); likewise, many Outer Mongols and Buriats perceive Inner Mongolians as having assimilated and become "Chinese" (personal communication, November 2012).

Buriats identify themselves with Buriat homelands. A Buriat focal child told me: "Lake Baikal is alive, sacred, and powerful." This sense of place serves as a way of constructing a past, of telling about cultural and personal history, and it is also a way to construct social traditions, which in turn, generate personal and social (ethnic) identities. As Basso (1996) stated: "We are, in a sense, the place worlds we imagine" (p. 7). Buriat families at home educated and socialized their children to respect and follow shamanism and Buddhist ideals, which advocate respect for the earth and the family unit. Buriat children were taught to obey and accede to their parents and elders' wishes. "We teach our children respect, to speak only when addressed," a Buriat parent explained, "and to revere their homeland. As Buddhists, they learn tolerance and compassion." Via Buddhism, Buriats also have a long tradition of literacy; both religious and secular education is highly valued. Yet for over 300 years, Buriats have interacted with Russians and participated in Russian based education (Montgomery, 2005). Unsurprisingly, contemporary Buriat culture has aspects of both Indigenous and Russian values. In fact, most Buriats speak Russian and have adopted Russian 
norms regarding food, dress, and education. The focal children, however, depicted ambivalent feelings ${ }^{3}$ about being both Buriat and Russian.

Likewise, in China, Han farmers and Mongol herders have been encountering each other for thousands of years (Tsui 2012) and this interaction, like that of the Buriat and the Russians, has been complementary and conflictive, dependent upon political, economic, and social circumstances. ${ }^{4}$ The way Inner Mongolian people lived and used the land for survival began changing during the late Qing Dynasty (1648-1911), when Han farmers began outnumbering Inner Mongolians herders (Bulag 2003). Mongol nomadic culture then declined; today, the Han control land resources and usage (Williams 2002). As China began moving from a planned to a market economy, government policy has not brought expected economic gains to Mongols. Instead, growth has accelerated grassland degradation (Williams 2002). Competition for resources and fear of losing their Mongolian culture and language have caused tensions, even violence, between the two groups (Geng and Gao 2012; Han 2011).

The Russian-based Buriat Mongolians also had a complex relationship with the Chinese, somewhat akin to Mexican migrants who settle in the US (Portes and Bach, 1985). A Buriat parent explained: "China is successful and powerful, a good place for education, but we are not Chinese." Notably, in past centuries, Buriats and Chinese were amiable trading partners: the cities of Kyathka and Ulan Ude (home to the focal children) served as two key Buriat cities for transporting tea and furs on the ancient Tea Route, an extensive and profitable commerce paralleling that of the Silk Road (Avery 2004).

In sum, the Buriats in Russia have not lived in isolation from other Mongolian worlds; they belong to a transnational community with ancient historical, economic, cultural and genealogical bonds. Buriats still migrate, but now they seek economic and educational opportunities instead of fertile pastures. In recent centuries the Buriats, like other Mongolians, have been politically, economically, and socially oppressed. Their homelands, their freedom to migrate and migration routes, are currently defined and controlled by Russia and China.

\section{Methodology}

This ethnographic study resembles that of Crago et al. (1993) and Phillips (1983), who explored how indigenous students attempted to learn in classrooms where the communicative practices they learned from their caregivers, as well as their indigenous mother tongue, differed from the school's. Tensions existed between indigenous home socialization and schooling, but this article emphasizes school-based observations. Fieldwork lasted 18 months, and involved watching focal children for 10-15 h a week in school, from September through May, with a winter break of five weeks in January/ February due to the Chinese Spring Holidays. Approximately six hours per week were also spent in Buriat homes and around Hohhot; three months were spent in Buriatia, living with focal families.

During fieldwork, I viewed language use in context, amid the children's social activities, in school, at home, and in other public places. I collected data by observing and questioning participants, and, as a participant observer, I also became involved in Buriat and Chinese daily life, watching, listening, asking questions, and gathering artifacts (Hammersley and Atkinson 2007) such as school memos, notes on fridges, Buddhist 
texts; children's SMS and email texts to me. Direct data sources included long-term passive observations, participant observations, as well as detailed field notes about observations and interviews of locals and insiders, and artifacts (Hammersley and Atkinson 2007).

To analyze data, I transcribed, translated, and coded the focal (and other) participants' speech acts, noting relationships and context, as speakers' choices and competence is co-constructed via interactions with others (Bakhtin 1981). Per Wolcott (1999), I then sought relevant patterns and themes by integrating other notes (reflexive notes, artifact data) and looking for ways to connect this information to the transcriptions and the interview notes. I used field notes and transcripts that focused on oral communication and social interactions (Wolcott 1999), describing and interpreting speech events, activities, or tasks in school, and other sites (Garrett and Baquedano-López 2002). To combat validity threats I acknowledged communicative context, as well as my researcher bias. Research allies helped me perceive the Han, Inner Mongolian, and/ or Buriat points of view; validity became a process negotiated via dialogue (Ross 2000). Diversity in sampling and in data analysis supported validity as well (Wolcott 1999). After hundreds of hours in different settings (school, homes, public gatherings, etc.) with participants, young and old, in China and in Buriatia, I began to understand how the focal children's communicative actions and social reality were connected to people in the past and to historical events, in the context of time and space, per a sociocultural framework utilizing Voloshinov and Bakhtin (1973; Bakhtin 1981).

In addition to focal children, other participants included adults - parents, professors, teachers, and administrators. School leaders were cordial to me because I had been vouched for by members of the Buriat community in Hohhot. Schoolteachers were cooperative, as they knew I was studying Buriat children's behavior, and not critiquing their teaching. The school viewed me as a Russian speaking foreign guest, who also understood Mandarin. When necessary, a Russian/Mandarin/Mongolian translator, a close friend of the principal, assisted me with interviews concerning the school's teachers and administrators. As an outsider, this study reflects my cultural limitations as a female, American-born scholar. To minimize my bias, I dressed and behaved modestly. I listened carefully, acted discreetly, and established rapport with my participants. Significantly, I conducted frequent member checks, among Buriats, Inner Mongolians, Outer Mongolians, and the Han Chinese.

\section{Working with the children: lessons, interviews and chats}

Conducting research with children presents unique ethical and methodological challenges, as children are vulnerable populations (James 2007). Seeking to combine traditional adult methods with two child-friendly methods (Balen et al. 2000), I offered dyads of focal children creative, communicative, game-filled English language lessons, which became a springboard for later discussions. During lessons, I praised their linguistic talents and diverted the focus away from me as the adult researcher. This in turn reduced the unequal balance of power between adult researcher/child participants (Balen et al. 2000).

During interviews, I simply listened as Kortesluoma et al. (2003) suggested, while children talked about their subjective views and experiences. Often, they spoke spontaneously and ignored any interview structure. At school, other children also often 
interrupted, or led my focal child away, which was very different than interviews (formal or informal) I held with parents and teachers. When interviewing, per Darlington and Scott (2002), I used open-ended questions conscious of the setting and child participants. Gradually, the children spoke more. I made mistakes, sometimes talking too much myself, or being stiff; I also made grammatical errors when speaking informal Russian. However, this endeared some of the children to me, as they saw me as vulnerable; in fact, a focal boy offered to give me grammar lessons.

School settings did not lend themselves to conducting formally structured child interviews. Instead, we chatted during class breaks (10 min), the morning exercise and patriotic speech break (20 min), or while walking back and forth to school (15 min). Via chat, I tried to capture a holistic picture of what was going on in the children's lives and what they thought was important. Chatting with them evoked charming and valuable information.

Parental presence during data collection was not as charming, but it offered valuable contextual information. It also constrained the things a child said, as I became just another adult, allied with the parent. For example, one parent/guardian constantly took control of the conversation. My attempts at trust building with a boy under her care failed until after he began taking English lessons privately with me, with his language partner. He had to gain trust in me before we could engage in an authentic dialogue (Kortesluoma et al. 2003).

\section{School site}

The Inner Mongolians, under Chairman Mao's directives, established the first minority autonomous region in China almost 70 years ago (Bulag 2000, 2003). Today, modern China remains keen on keeping "borderland minorities," Mongolians, Tibetans, and Uighurs, from attempting to secede (Han 2011). In the 1980s, bilingual practices and educational concessions for Chinese minorities were reaffirmed and enhanced (Tsung 2009). The school site (hereafter school), an outcome of these policies, attracted some Russian Buriats, who first created the micro-community in Hohhot in 2004.

My primary research school site, a combined primary and middle school, was a statefunded bilingual boarding school with approximately 1700 students. In the past the school offered places to non-Chinese Mongolian students and to other international students, including Japanese, Korean, Russian, Central Asian, etc. In 2012, only Outer Mongolian and Buriat international students attended. As a combined primary/secondary school, it had two dormitories, one for foreign students and one for Inner Mongolian children from the northern grasslands. In 2012, the school's main student body studied in Temut Mongolian (a standard Mongolian variety in Inner Mongolia, especially Hohhot) for all primary and secondary courses, excepting English and Mandarin language classes. In 2012, more than $90 \%$ of the students were urban Chinese Mongolian children from Hohhot. The remaining Chinese Mongolian students came from northern grasslands; the foreign Mongolian students came from Outer Mongolia and Russia. In 2012, the school had 88 teachers, all of them ethnically Mongolian by self-identification (with six from Outer Mongolia), and all were bilingual in Mongolian and Mandarin. All had completed three years of university teacher training; seventy percent of them held additional advanced teaching certification. 


\section{Mongolian track and Mandarin track}

The school termed itself a bilingual institution but it could also be described as a heritage language school. As one Buriat parent said, "It's really for those Chinese Mongols who don't understand much Mongolian, but because teachers use both languages, it's good for us, too." Buriat parents expected their children to acquire literacy in both Mongolian and Mandarin. In fact, school administrators had created a special Mandarin Language Track for their international (Kirghiz, Kazak, Tatar, Kalmyk, Khalkha, Buriat) Mongolian students. This section consisted of two levels, year one and year two, with smaller classes (22-30 students); in 2012 only Khalkha (Outer Mongolians) and Buriats (Russian Mongolians) had enrolled. Most Buriat parents viewed this track as a quick, comprehensive way for their children to gain fluency in Mandarin; their children also studied Mongolian with language tutors for three hours on Sundays. This track did not follow Chinese state curriculum standards, focusing instead upon intensive Mandarin language studies (grammar, reading, HSK vocabulary, conversation) designed to prepare foreign students to pass the state Chinese Foreign Language Exam (HSK) within two years. Other classes, math, science, art, were optional. In the Chinese track, the teacher spoke in Mandarin Chinese, but frequently codeswitched, using Temut Mongolian. Khalkha (Outer Mongolians) could understand this variety easily, but I watched as Buriat Russian students struggled and scrambled constantly, looking up words in their Russian/Chinese dictionaries. Three Buriats: Surana (Year 1) Bata-Nimah, and Mergen (both Year 2), were enrolled in this track; only Dasha, the biracial Buriat girl, was enrolled in the standard Grade 4 Temut Mongolian track.

The Temut Mongolian track had crowded classrooms (55-65 students), with the primary grades of one through six in the main building. Dasha, enrolled in Grade 4, studied nine subjects a week, including three languages; math, geography, music/art, computer, PE, ethics, and English, Chinese, and Mongolian languages. Dasha's mother had placed her daughter in the Mongolian Track because "I wanted her to really learn Mongolian well, not just pick it up from classmates and tutors. Because we live in China she will naturally learn Chinese." Dasha, a Russian monolingual, did not receive any special Mandarin tutoring. Dasha said that it was "hard, really hard at first, to understand anything at all" during her first year; I observed her struggles during her second year at school, while she attended Grade 4 in the Mongolian track.

\section{The focal children and other participants}

This study focused upon four focal participants, Buriat youth (12-15 years old) from Buriatia, Russian Federation, with children having prior residence in Ulan Ude (Mergen, Dasha), the capital city, or in the outskirts of Ulan Ude (Surana), and one (Bata-Nimah) coming from Kyathka, (near the Outer Mongolian and Russian border) (Fig. 2). I found them by informally asking around the Buriat community. One parent mentioned my

\begin{tabular}{|l|l|l|l|l|l|}
\hline Name & Age & Gender & Track & Ethnicity & Hometown \\
\hline Dashka & 12 & Female & Mongolian & Mixed race & Ulan Ude \\
\hline Mergen & $141 / 2$ & Male & Chinese & Buriat & Ulan Ude \\
\hline Surana & 12 & Female & Chinese & Buriat & Ulan Ude \\
\hline Bata Nimah & 14 & Male & Chinese & Buriat & Kyatka \\
\hline Zhargal & 15 & Male & $\begin{array}{l}\text { Mongolian } \\
\text { (graduated) }\end{array}$ & Buriat & Ulan Ude \\
\hline
\end{tabular}

Fig. 2 List of focal participants 
project to another, and shortly after establishing myself again in Hohhot, I had many enthusiastic participants, including parents, teachers, and city locals (Han, Mongol, or Buriat). In addition to focal children, I interviewed young Buriat bilingual school graduates, and young Mongolians and Buriats attending the university that sponsored my visa. I also met and interviewed many Buriats in Buriatia.

\section{Contrasting sociocultural beliefs: Chinese sensibilities}

The Chinese educational system serves millions of students (Liu et al. 2000). Today, Chinese parents work long hours in the hopes of creating a better life for their children. Parents expect their children to make great efforts at school (Liu et al. 2000). "Success here (in China) is measured in terms of economic success," said Dr Liu, a university professor; "Men are chained to their work. Few change jobs, and salaries don't get raised regularly. But people are grateful for work; there are too many people, and not enough jobs." As Chinese adults are chained to the jobs, Chinese children are metaphorically chained to their schools. They attend one school for many years and spend long hours in school, and many hours doing homework. Students rarely change schools. They are expected to view their studies as a job, which will secure their future as well as provide them with a way to eventually care for elderly parents. "No one is really free...First we provide for them (children), and then, later, they provide for us, that is the Confucian Way," explained Wang Jie, my Chinese tutor in Hohhot.

Chinese parents seek to get their child admitted to the best school possible, and they will struggle to help their child succeed. Education equates with success; success means steady work and income. Field (1995:54) in discussing Japanese schools, argued that students suffer from "the soft violence of endless labor," as they go about their daily lives at school and at home. Chinese youth, like Japanese youth, attend school for long hours during the day, and then Chinese parents take them to cram schools until late at night; some also have private lessons, in math, music, etc. This leaves very little time for play, physical exercise, or even the chance to watch television or play video games to relax. Field (1995:55) calls such Japanese children pampered hostages because parents also make extraordinary demands on their children to perform academically. Likewise, Chinese parents said this workload is necessary because "there are too many people... too much competition ... ordinary teachers are not good enough."

To my American eyes, the Chinese bilingual school appeared highly structured with large (50-65) classes. Teachers drilled students to submit as well as to learn; they delegated monitors, and established rules and rituals that served to build group esprit. "We organize them this way to control them; they are too many," said Saranchana, a Mongolian track language teacher; "Our job is to make them obey, not to play." Every week, a classroom's performance was compared to other classes in the same level. In this way, Chinese students were socialized in school to act as a group, because they are taught and addressed, rated and ranked, in groups. Inner Mongolian children understood hierarchical political structures and power flow. For example, in the Mongolian track class, every week the teacher assigned three class officers who excelled and obeyed to distribute papers, collect papers, hand out books, collect books, and run errands. He or she was much envied. Yet Dasha never was a class officer; she treated her peers with great scorn when they handed her paper or books. Dasha told me: "In Russian schools, we had class monitors, but we chose them; these are little Nazis." 
Indeed, Russian/Buriat and Chinese/Mongolian classrooms contained different power dynamics. In this school, the Inner Mongolian teachers, following Han ideology (Liu et al. 2000) had absolute authority and control over students. They controlled all talk and movement, and all significant actions and interactions. The teachers trained them to move-sit, stand, salute, respond, and exit-in group formation. Only rarely would a teacher single out a child, and ask for a direct, individual response. Such participant structures (Philips 1983), ways of behaving, communicating, and interacting, promoted positive social behavior, according to Han Chinese norms, which seemed based upon ancient Confucian hierarchy combined with modern communist crowd control. Any Chinese child who refused to obey was punished, either verbally and/or corporally. Class demographics, as much as ideology, have influenced this Han Chinese point of view.

"To be an excellent teacher, you must be effective in managing large classes," said Dochin, a Mongolian track teacher. She outlined three important structures: class discipline, time management, and rules and rituals. "The discipline is from me, I pass it to the monitor," she explained, "I get the class to act as a group, to save time; we do things as a group, not as one." This teacher added, when I asked, that Mongolian norms were taught, but "only as a way to preserve culture, not really used in class...you know, how to enter a yurt, how to take a bowl of milk..."

Despite the fact that the school research site was a Mongolian minority serving institution, there were constant reminders demanding loyalty to the Han-dominated Chinese state. As demonstrated by Shirazi (2012) one key educational focus for all students was the positive presentation of the government as a benign ruler (Liu et al. 2000), a big brother to minority peoples. In this school, at times, this included a rewriting of history regarding the Mongolian people; for example, not all Mongolians supported Chairman Mao's rise to power (Bulag, 2002). Conformity to Chinese rule also included depicting Mongolian children in Mongolian dress as loyal Chinese citizens by adding 'young pioneer scarves' to their national costume to show loyalty and enthusiasm toward Chinese communism. Also, important announcements, written or oral, were in Mandarin, as opposed to Mongolian. Like Shirazi's (2012) Palestinian boys in Jordan who did not feel motivated to be loyal to an alien nation, Bata-Nimah, a Buriat boy commented; "I didn't grow up in Soviet times. I don't want to start doing this (commie) stuff now."

Another major force of Chinese school socialization focused on standardized testing and constant assessment. The Chinese take testing very seriously; it is an ongoing process, from primary school through university, with testing socializing children to conform and to obey (Borchigud 1995). In addition, testing sends the message that others will evaluate the child's worth, based upon national criteria established by the Chinese State (Bulag 2003). Testing socializes youth to focus on where one belongs in society. At this school, testing established hierarchies between students, and instilled the idea that children, as future workers, must not only have social skills but also be competitive in order to survive (Heller and Jones 2001).

As in other Chinese schools, students must pass standardized tests to graduate from middle school to high school (Tsung 2009); high school students must pass a standardized college entrance exam which ranks their scores to determine 
which university they may attend, if any (Borchigud 1995). In addition to passing courses, foreign students must pass the HSK, a standardized Mandarin language test. Educational assessment is nationally standardized and monitored by the state and by regional authorities (Wang 2013). Critical educational scholars assert that such constant testing and constant competition could result in students being unlikely to oppose the absolute authority of those ruling (Heller and Jones 2001). All testing was conducted in Chinese; there were no assessments for Mongolian fluency. Thus, students, domestic or international, encounter difficulties obtaining institute and university places, and future jobs, if their skills in written and spoken Chinese are inadequate.

\section{Contrasting sociocultural beliefs: Buriat sensibilities}

For Buriat focal children, school culture differed in Hohhot, Inner Mongolia, China, from that in Ulan Ude, Buriatia. Some children refused to conform to the broader norms established by the school and with the expectations, conscious or unconscious, their teachers had for them as students. Firstly, in contrast to their Chinese peers, who passively accepted the workload, Buriat children did not like the long hours of classroom study and massive amounts of homework. They complained to me vehemently about assignments, and said "at home" (Buriatia) they had time to "play." Likewise, Buriat parents did not, like Chinese parents, socialize their children to work as hard and compete as keenly with their Chinese classmates. Certainly, Buriat parents expected their children to do well at school, but they also wanted their children to think widely; "My son should read Tolstoy, and ride his bike, and go home (during holidays) to see his family...this Chinese system is too harsh on children," said Bata-Nimah's father. Buriat parents socialize their children to respect the earth and play outside in nature. In Hohhot, an urban city of three million, Buriat children had little access to nature.

Second, Buriat children did not like the authority structure in the bilingual school. Students in Buriatia, like students in China, viewed teachers as authorities, who fed them information, but Buriat students also viewed their teachers as accessible. "In Ulan Ude, we could see our teacher as a person, and knew she liked us. Here we are just taking up space, competing with the others," Mergen said. This sense of being invalid, "just taking up space" made the Buriat children unenthusiastic. They also lacked genuine chances for student-initiated responses. "We are supposed to be quiet, and not make trouble. The teacher is always yelling at us and telling us how bad we are," said Bata-Nimah. He also reported that he was able to "chat" with his teacher on the playground in his Russian school and that he felt "more comfortable" around his "Russian teachers" back home than his "Chinese teachers" in Hohhot.

Russian schools in Buriatia and elsewhere in Russia, from primary through university, are noted for their mobility and chaos. Hudgins (2003:252) reports that, from primary through university levels, "constant chatter" occurred. Unstructured social interaction between students is now expected and allowed in Russia. In Buriatia, teachers (ethnic Buriats and ethnic Russians) told me that they expected the students to get up, to talk, and to confer individually with me and with others during certain class times. These Buriat teachers had smaller classes (20-25 students) but like the Chinese they understood classroom discipline, time management, rules, rituals, and procedures. The 
difference laid in the teacher's visions; "We want creativity, not soldiers," said Ayuna, a Buriat teacher in Ulan Ude.

In Hohhot, Dasha remarked, "I hate sitting, being quiet; it's stupid. It's boring." The two Buriat boys rarely whispered or talked in class, while their Outer Mongolian classmates had a rising noise level. This angered the Inner Mongolian teachers, who would shout: "Be quiet! Have respect!" While Inner Mongolian students told me they "liked" to act as one unit, shouting out answers chorally, Buriat students told me they did not like to respond chorally. In Buriatia, they had raised their hands to volunteer to speak, and they wished to speak and to be assessed as individuals. Differences in relations of power between student and teacher also upset the Buriats; "We have no rights here; we can't ask questions, and they treat us (students) as a herd of sheep," said Mergen. "We don't think, we just recite, baa baa baa, as one large group."

Although Russian classes, after kindergarten, do not encourage as much group work, team activities, or communicative language learning as American schools, nevertheless, teachers can and do utilize these teaching methods to some extent (Holmes et al. 1995). For example, I observed as Buriat teachers asked open questions to individual students; "This dialogue allows creativity, and allows students to choose good partners for pair and group work," said Valentina Vasilyevna, a retired master teacher in Ulan Ude. Surana, who attended the Chinese track but left within three months, said: "My class at home (in Ulan Ude) has 24 students. We do stand to greet our teacher, and I stand to answer questions, but it's different. It's respect (standing up), not the army, you know. And it's my answer." This child also confirmed that in Ulan Ude she could chat with her friends during class, and choose to get out of her seat at times. She also had cordial interactions with her Russian teachers; Surana took me to visit Valentina Vasilyevna in her home.

Currently, teachers in Russia cannot use corporal punishment (Holmes et al. 1995), but in the Mongolian track classes where Dasha sat, Inner Mongolian teachers held pointers, which they used to rap on students' hands. In the Chinese track, I saw a teacher pick up a notebook and lightly slap a student on the side of his head. This was not acceptable to the Buriats; "If she dares to touch me, I'll slug her," Dasha, told me, regarding corporal punishment. Zhargal, (aged 15) another Buriat participant who had recently graduated from the school, added: "They cannot hit us in school (in Buriatia); it is against Russian law. No one ever hit me in primary or secondary school. My mother said, in Soviet times, they did that, but not after 1991."

Peer interactions were also problematic. For example, Inner Mongolian students blatantly rejected Dasha for her non-conformance and non-participation by ignoring and ridiculing her. Her peers told me she was "a bad student." Dasha, identifying herself as "half Russian and half Buriat," said: "They always called me fatty foreigner. I hated going to school. I hate the Chinese." However, when chatting at the school gates with an Inner Mongolian mother whose child was in this class, she said: "In China, the class is considered as a group; all the marks are averaged together. If one child refuses or cannot do well, other children will resent her, even act mean. She (Dasha) is not only a foreigner, different, but also lazy. She holds her group back."

A third issue is that Russian schools are no longer highly focused on patriotic education (Holmes et al. 1995), while Chinese school socialization continues to stress loyalty to the government. Some Russian educators worry about this loss while others rejoice 
in turning more toward European standards (Griswold 2007). On the exercise yard, I watched Buriats mock the Chinese patriotic rituals, especially during the daily midmorning break, when all students marched out to the field, staying in class formation and performing standardized exercises in time to music and patriotic slogans blaring from microphones. Their teachers strolled up and down their students' lines, watching them and making sure that they did their exercises. Sometimes teachers yelled at a student, or cuffed him to get him in line. This type of physical exercise differed from what Buriat children experienced in Buriatia, where out of class they could approach and hold more authentic dialogues with their teachers, and where they could choose whether to exercise or not during the morning exercises. "We did what we wanted at home; played volleyball, or basketball, or just smoked and chatted," Mergen, said, adding: "Marching is for soldiers."

\section{Assessment in Russia and for the Buriat in China}

Assessment measures have been changing in Russia since 1993, when Russian educators started looking at the European system of testing and teaching (Holmes et al. 1995). Schools have diversified, and teachers have more teaching freedom. In 2001, the Russian government mandated policy directed at outcome based school curriculum and subsequent assessments, rather than rote memorization (Lenskaya 2013). Russian high school students also have more choices regarding the breadth and depth of their studies. They must take the so-called Unified Exam, to qualify both as high school graduates and to be eligible for university. Lenskaya reports that these assessments resemble the SATs in the USA.

As in China, cheating does occur in the Russian Federation; Hudgins (2003) offered her opinion that post-Soviet education also condones both cheating and plagiarism at all educational levels. Yet significantly, regarding Dasha, her teachers all ignored not only cheating but also any aspects of this child's lack of learning, as well as other negative behaviors. Moreover, although they were self-professed "Mongolians," as teachers they presented a Chinese lack of response toward non-Chinese students, which was done to avoid conflict with foreigners (Ting-Toomey 1999). These Buriats, as foreigners, seemed academically overlooked by their teachers, who, following Han ideology, saw them as outsiders, whom they treated kindly - but indifferently regarding their learning. If they caused no trouble, they could break rules - but their academic performances seemed moot.

\section{Buriat resistance strategies}

In the Mandarin/Mongolian bilingual school, during breaks between classes, the teachers always left the room. Then the Inner Mongolian students (and often the Outer Mongolian students) would scream, shout, push, shove, and run in the halls. During break times, Buriat children in the sheltered Chinese class would move out into the hallway to meet each other and chat quietly, watching the ruckus. They did not engage in the mayhem, using this time to talk to each other in Russian, and watch how the other children behaved. Bata-Nimah remarked: "They (Outer and Inner Mongols) are peasants. They think they are better than us, because they speak Mongol and we speak Russian. But we are classy and they are just herders with a little money." Thus, break 
times for these Buriats offered them a way to assert their superiority over their fellow Mongols, Inner and Outer, by acting with restraint.

The Buriat boys' language choices also displayed resistance. If the boys used a Mongolian language, they chose to use Khalkha Mongolian, the language of Outer Mongolians. They did not speak in Buriat, nor in Temut. I asked Bata-Nimah why, and he said: "No one tells them (Khalkha) what to do." Thus, the Buriat boys recognized political and ideological boundaries via their linguistic choices.

Another resistance strategy was refusal. "I will not raise my hand in that stupid way," Dasha told me. "And I will not move my seat; I like being in the back. It's stupid." Sadly, it became clear to me that despite the fact she had sat in the Mongolian track class for two years, over $50 \%$ of the information spoken in Mongolian and in Chinese was unknown or unclear to her. Instead of trying to catch up or keep up with her peers, Dasha's strategy was to stay in the back corner and play with her phone, IPod, and/or IPAD using Russian. Unfortunately, her strategy of refusing to participate also undermined her chances for gaining much communicative competence in either Mongolian or Chinese.

Another example of refusal concerned school dress code, which in China represents an indirect form of social control over students. Hairstyle, uniform, and electronics are part of this control. Dasha's clothing (jeans, jewelry, makeup), were forbidden at school, and considered as high status symbols among all the children. However, teachers and authorities ignored the fact that she and other Buriats did not wear the mandatory school uniform, and they also brought forbidden items to school (phone, IPad, Ipod), using them openly. Thus, Buriat defiance toward the school dress code symbolized resistance, against Han ideology that demanded assimilation.

\section{Conclusion}

As Philips (1983) demonstrated, when teachers' cultures (Anglo) and students' cultural interaction styles (Native American) differ, learning may be impaired or misunderstood. Likewise, many Chinese school systems still advocate a teacher-centered learning style, placing students in highly structured formations and group-oriented situations. Such Chinese structures oppose the post-Soviet Russian, student-centered teaching style (Holmes et al. 1995; Hudgins 2003) with which the Buriats were familiar. Ironically, despite the fact that the teachers at this school overwhelmingly self-identified as "Mongolian" in ethnicity, their teaching practices and expectations, and their participant structures, conformed to the Han Chinese ideology. Such covert ideology hearkens us back to Heath's (1983) extended study of three communities in the USA, where certain groups of children were academically challenged by a disconnect between their community's socialization practices and the school's practices. Likewise, Philips' (1983) study of indigenous children reflected a similar disconnect, despite the fact that Native American children were fluent in the dominant language, English (Lee 2009).

Little research on multilingual socialization, particularly in classrooms, has examined non-Western cultures and languages (Moore 2009). Classroom settings can also reveal how teachers and students cultural practices are shaped by larger, historical social patterns that serve those in power. For example, like many US schools accommodating Mexican migrants Valdés 2001; Foley 1990), this school had a submersion perspective, as opposed to immersion, transitional, or maintenance outlooks. None of the teachers 
spoke Russian or Buriat and no special needs educators, or classes, were provided to help the Buriat children learn more effectively. Significantly, although Buriats are Mongolian speakers, their language variety differs linguistically from Temut Mongolian. Buriat students experienced two new languages, as well as encountered Chinese educational norms and ideology, which strictly demanded their compliance. At school, Buriat ways of behaving, communicating, and interacting, which centered upon being treated as intelligent, unique individuals, with the right to communicate politely but spontaneously with adults, were overlooked and ignored. As a result, like Paul Willis' (1977) 'lads', some Buriats acted with restraint, some refused to learn, some even challenged the Chinese legal system. Although these young Buriats had agency to choose their actions, history and politics also impacted their behavior as students in China (Voloshinov and Bakhtin 1973).

Antonio Gramsci (1971) defined hegemony as power achieved via both coercion and consent, arguing that the ruling classes achieve domination not by force or coercion alone, but also by causing subjects to willingly submit. Hegemonic states exercise power and secure acquiescence first by manipulating material incentives, via threats or promises of reward, which serve to alter political and/or economic incentives. Hegemons can also exercise power via educational practices, which alter core beliefs, causing youth to internalize hegemonic norms and values. Education can effectively serve as a process of cultural transmission in order to reproduce the dominant culture (Bourdieu and Passeron, 1977).

For the Buriats, their incentive was ultimately to offer their children a Mongolian medical education, as these practices had been lost in Russia. If the Buriat youth passed the Mandarin language requirements for foreign students, they could be admitted to the medical institute (personal communication, November 2012). Buriat parents, however, did not initially realize that the children must run an ideological gauntlet at the bilingual school, which demanded their compliance to Han Chinese norms. Inner Mongolian teachers and students had internalized and accepted Han hegemonic norms at the bilingual school, as the school served both as an ethnic incentive and as a Han ideological tool. But Buriat students actively resisted school practices.

Ironically, in resisting, Buriat children identified themselves not as members of a pan-Mongolian alliance, but as Russian citizens - members of another hegemonic state. For them, being Russian meant being powerful, as historically Russians had dominated over not only over the Mongols, but also over the Chinese. Had then these young Buriats assimilated and internalized Russian norms at the price of their Buriat ethnicity? I think not, because the Buriat students and their parents held two specific goals regarding educational outcomes in China. First, pass the gatekeeping HSK exam; second, enter the Hohhot Mongolian medical institute. Thus, their ultimate goal supported a Buriat Mongolian worldview, by offering a Mongolian profession revered by devout Buriats. The challenge, however, was for young Buriat students to navigate smoothly through school practices incorporating Chinese culture in Inner Mongolia, which like Russian culture in Buriatia, offered them little empathy or equality. Their long hours at school also impacted their cultural identity. These Buriats understood that the Inner Mongolians had assimilated to Han norms: they made no attempt to speak Temut Mongolian, but understood that they must learn to speak in Mandarin, and to read in Classical Old Mongolian. At other times the young Buriats identified 
themselves as Russian citizens, knowing that Russia, historically has been dominant over China. With Outer Mongolian peers, at times the Buriat boys attempted to speak in Khalkha; these Buriats wanted to associate and identify themselves with Mongolians who were "free" from hegemonic forces (Russia and China). The Buriats understood that Inner Mongolians, like their people (Buriats) in Russia, were not members of the dominant culture. The linguistic choices of these young Buriats symbolized their resistance against dominant ideologies, and can also represent their cultural identity. In the future, I will research and analyze the way linguistic choice links with identity performance for multilingual youth such as these young Buriats. Thus, despite the fact that the youths presented here are Buriat, they can also be seen as global members of postmodern indigenous youth who are influenced by hegemonic global processes, as well as historical colonization processes.

China, and post-Soviet Russian Buriatia have undergone dramatic political, economic and social changes in recent decades, resulting in complex and sometimes conflicting linguistic and cultural practices - that in turn impact their respective educational systems. Bakhtin's (1981) dialogical theories have shown how cultures and people evolve and change over time via social interaction, while critical theorists explore how nonmainstream culture and people are shaped and defined by those in power. In China, young Buriats engaged in a dialogical struggle, as they interacted with their Chinese teachers and peers. Resisting school norms, they negotiated and built their own perspectives. The result was an ongoing and multifaceted performance of Buriat identity that relied on both Buriat and Russian perspectives. Educators, researchers, and policymakers must consider the implications of hegemonic educational practices for Indigenous and/or migrant student populations everywhere. As educators, we must understand how those in power define and control linguistic and material resources directed at our students.

\section{Endnotes}

${ }^{1}$ Author's note: In China, medical institutes, including the one described, do not require a university degree for entrance. In the case of the Buriat entering this medical institute, all that was required of them was to be over the age of fifteen and to have scored "five" - the highest level of proficiency on the HSK (Chinese state language exam). Interviews with Buriat families brought to light their focused intent on this particular medical institute located in Hohhot, Inner Mongolia. They believed, along with the local Han and Mongolian population, that this institute had preserved valuable medical procedures, along with recipes for herbal medicine, that had been brought to the Mongolian peoples by Tibetans. Parents also reported that, if for any reason a child did not enter the institute, he or she would either return to Buriatia to seek employment, or try to work in Outer Mongolia, as the employment laws and restrictions in China did not offer many work opportunities for Russian citizens.

${ }^{2}$ Mr. Putin's interest in Siberian resources as an economic bargaining tool has been ongoing since his ascent to power. For example, refer to: Cornelius, Peter, and Jonathan Story (2008). China and global energy markets. Orbis 51.1: 5-20 and also: Peterson, D. J., and Eric K. Bielke (2001). The reorganization of Russia's environmental bureaucracy: implications and prospects. Post-Soviet geography and economics 42.1 (2001): 65-76. 
${ }^{3}$ Other scholars who study Indigenous youth that inhabit spaces controlled by dominant cultures have noted similar ambivalence. Dr. Tiffany Lee commented to me in March 2014 similar findings regarding Navajo youth in the United States, for example.

${ }^{4}$ In 2002, Dr. Uradyn E. Bulag, a native Inner Mongolian, currently a scholar at Cambridge, published a comprehensive and fascinating book on this subject.

Competing interests

The author declares that she has no competing interests.

Received: 2 February 2015 Accepted: 1 September 2015

Published online: 17 September 2015

\section{References}

Avery, Martha. 2004. The Tea Road. Beijing: China Intercontinental Press.

Bakhtin, Mikhail. 1981. The Dialogic Imagination: Four Essays. Michael Holquist, trans. Austin: University of Texas Press.

Balen, Rachel, Claire Holroyd, Gary Mountain, and Barbara Wood. 2000. Giving Children a Voice: Methodological and practical Implications of Research Involving Children. Pediatric Nursing 12(10): 24-29.

Balzar Mandalstam, Marjorie. 2011. Shamans, Spirituality and Cultural Revitalization. New York: Palgrave Macmillian.

Bao, Wurlig. 1994. When is a Mongol? The process of learning in Inner Mongolia. Ph.D. dissertation. Seattle: University of Washington.

Basso, Keith. 1996. Wisdom sits in places: Landscape and language among the Western Apache. UNM Press. Albuquerque: NM

Borchigud, Wurlig. 1995. The Impact of Urban Ethnic Education on Modern Mongolian Ethnicity 1949-1966. In Cultural Encounters on China's Ethnic Frontiers, ed. Stevan Harrell, 249-302. Seattle: University of Washington Press.

Bulag, Uradyn. 1998. Nationalism and hybridity in Mongolia. Oxford: Clarendon.

Bulag, Uradyn. 2000. From Inequality to Difference: Contradictions of Class and Ethnicity in 'Socialist' China. Cultural Studies 14(3/4): $531-561$.

Bulag, Uradyn. 2002. The Mongols at China's Edge. Oxford: Rowman \&Littlefield.

Bulag, Uradyn. 2003. Mongolian Ethnicity and Linguistic Anxiety in China. American Anthropologist 105(4): 753-763.

Bourdieu, Pierre, and Jean Paul Passeron. 1977. Reproduction in Education, Society and Culture. London: Sage Publications.

Crago, Martha, Betsy Annahatak, and Lizzie Ningiuruvik. 1993. Changing patterns of language socialization in Inuit homes. Anthropology and Education Quarterly 24(3): 205-223.

Cummins, Jim. 2000. Language, power, and pedagogy: Bilingual children in the crossfire (Vol. 23). Bristol, UK: Multilingual Matters. Bristol: UK.

Darlington, Yvonne, and Dorothy Scott. 2002. Qualitative Research in Practice: Stories from the Field. Buckingham: Open University Press.

Field, Norma. 1995. The Child as Laborer and Consumer: The Disappearance of Childhood in Contemporary Japan. In Children and the Politics of Culture, ed. Stephens Sharon, 51-79. Princeton: Princeton University Press.

Fordham, Signithia. 1996. Blacked Out: Dilemmas of Race, Identity and Success in Capital High. Chicago: University of Chicago Press.

Foley, Douglas E. 1990. Learning capitalist culture: Deep in the heart of Tejas. University of Pennsylvania Press. Philadelphia: PA.

Forsyth, James. 1992. A History of the Peoples of Siberia. Russia's North Asian Colony 1581-1990. Cambridge: Cambridge University Press.

Garrett, Paul P, and Patricia Baquedano-López. 2002. Language Socialization: Reproduction and Continuity, Transformation and Change. Annual Review of Anthropology 31: 339-361.

Geng, Xiaoming, and Gao Guorong. 2012. A Case of Over Cropping: Causes and Consequences of Qing Dynasty Approval to Plough and Plant the Inner Mongolian Grasslands. Nomadic Peoples 16(1): 21-35.

Graber, Kathryn. 2012. Knowledge and Authority in Shift: A Linguistic Ethnography of Multilingual News Media in the Buryat Territories of Russia. Ph.D. dissertation, Department of Anthropology, University of Michigan. Ann Arbor: M

Gramsci, Antonio. (1971). Selections from the Prison Notebooks of Antonio Gramsci: Ed. and Transl. by Quintin Hoare and Geoffrey Nowell Smith. G. Nowell-Smith, \& Q. Hoare (eds.). International Publishers. NY: NY.

Griswold, Wendy. 2007. Transformative Learning in a Post-totalitarian Context: Professional Development among Schoolteachers in Rural Siberia. Ph.D dissertation, Department of Adult Education, Kansas State University. Lawrence: KS.

Hammersley, Marytn, and Paul Atkinson. 2007. Ethnography: Principles in Practice. London: Routledge.

Han, Enze. 2011. The Dog that Hasn't Barked: Assimilation and Resistance in Inner Mongolia. Asian Ethnicity 12(1): 55-75.

Harrell, Stevan (ed.). 2013. Cultural Encounters on China's Ethnic Frontiers. Seattle: Univ of Washington Press.

Heath, Shirley Brice. 1983. Ways with Words: Language, Life and Work in Communities and Classrooms. New York: Cambridge University Press.

Heller, Monica, and Martin Jones (eds.). 2001. Voices of Authority: Education and Linguistic Difference. Westport: Ablex. Holmes, Brian, Gerald H Read, and Nataliyia M Voskresenkaya. 1995. Russian Education: Tradition and Transition. NY: Garland. Hudgins, Sharon. 2003. The Other Side of Russia: A Slice of Life in the Russian Far East. College Station, TX: Texas A\&M Press. Humphrey, Caroline. 1996. Buryatia and the Buryats. In The Nationalities Question in the Post-Soviet States, ed. Smith Graham, 113-125. New York: Longman.

Humphrey, Caroline. 2002. The unmaking of Soviet life: everyday economies after socialism. New York: Cornell University Press.

James, Allison. 2007. Giving Voice to Children's Voices: Practices and Problems, Pitfalls and Potentials. American Anthropologist 2(109): 261-272. 
Khilkhanova, Erzhen, and Doiji Khilkhanov. 2004. Language and Ethnic Identity of Minorities in Post-Soviet Russia: The Buriat Case Study. Journal of Language, Identity, and Education 3(2): 85-100.

Kortesluoma, Riita-Liisa, Maija Hentinen, and Merja Nikkonen. 2003. Conducting a Qualitative Child Interview: Methodological Considerations. Journal of Advanced Nursing 42(5): 434-441.

Kwong, Julia, and Hong Xiao. 1989. Educational equality among China's minorities. Comparative Education 25(2): 229-243.

Lee, T. S. (2009). Language, identity, and power: Navajo and pueblo young adults' perspectives and experiences with competing language ideologies. Journal of Language, Identity, and Education, 8(5): 307-320.

Lenskaya, Elena. 2013. Russia's Own Common Core. Phi Delta Kappan 95(2): 76-77.

Liu, Judith, Heidi A Ross, and Donald P Kelly (eds.). 2000. The Ethnographic Eye: Interpretative Studies of Education in China. New York: Taylor \& Francis.

McCarty, Teresa, Romero-Little Mary Eunice, Warhol Larisa, and Zepeda Ophelia. 2009. I'm Speaking English Instead of My Culture: Portraits of Language Use and Change among Native American Youth. In Ethnolinguistic Diversity and Education: Language, Literacy, and Culture, ed. Farr Marcia, Seloni Lisya, and Song Juyoung, 69-98. New York: Routledge.

Meyer, Lois, and Benjamín Maldonado Alvarado (eds.). 2010. New world of indigenous resistance: Noam Chomsky and voices from North, South, and Central America. New York: City Lights Books.

Montgomery, Robert. 2005. Late Tsarist and Early Soviet Nationality and Cultural Policy: The Buryats and their Language. Lewiston: Edwin Mellen Press.

Moore, Leslie. 2009. On communicative competence in the field. Language \& Communication 29(3): 244-253.

Ochs, Elinor. 1998. Culture and Language Development: Language Acquisition and Language Socialization in a Samoan Village. Cambridge: Cambridge University.

Ochs, Elinor, and Bambi B. Schieffelin. 2011. The Theory of Language Socialization. The handbook of language socialization Duranti, Alessandro, Elinor Ochs, and Bambi B. Schieffelin, eds. pp. 1-11

Paulston, Christina Bratt. 1994. Linguistic Priorities in Multicultural Settings. Philadelphia: John Benjamin.

Philips, Susan. 1983. The Invisible Culture: Communication in Classroom and Community on the Warm Springs Indian Reservation. New York: Longman.

Portes, Alejandro, and Robert L Bach. 1985. Latin journey: Cuban and Mexican immigrants in the United States. Berkeley: University of California.

Postiglione, Gerald (ed.). 1999. China's National Minority Education: Culture, State, Schooling and Development, vol. 1090. New York: Routledge.

Romero, Mary Eunice. 2003. Perpetuating the Cochiti Way of Life: A Study of Child Socialization and Language Shift in a Pueblo Community. Ph.D dissertation, Department of Education, University of California. Berkeley: CA.

Romero-Little, Mary Eunice. 2010. How Should Young Indigenous Children be Prepared for Learning? A Vision of Early Childhood Education for Indigenous Children. Journal of American Indian Education 49(1and 2): 1-25.

Ross, Heidi A. 2000. Chapter Six: In the Moment - Discourses of power, narratives of relationships - Framing ethnography of Chinese schooling, 1981-1997. In In The Ethnographic Eye: Interpretative Studies of Education in China, ed. Judith Liu, Heidi A Ross, and Donald P Kelly, 123-153. New York: Taylor \& Francis.

Rossabi, Morris. 2005. Modern Mongolia: From Khans to Commissars to Capitalists. Berkeley: UC Press.

Schwartz, Harry. 1968. Russia and China. Horizon 10(1): 4-21.

Shirazi, Roozbeh. 2012. Performing the 'Knights of Change': Male Youth Narratives and Practices of Citizenship in Jordanian Schools. Comparative Education 48(1): 71-85.

Sneath, David. 2010. Political Mobilization and the Construction of Collective Identity in Mongolia. Central Asian Survey 29(3): 251-267.

Ting-Toomey, Stella. 1999. Communicating Across Cultures. New York: Guilford Press.

Tsui, Yenhu. 2012. Swinging between Nomadism and Sedentarism: A Case Study of Social and Environmental Change in the Nomadic Society of the Altay Steppes, Xinjiang. Nomadic Peoples 16(1): 50-67.

Tsung, Linda. 2009. Minority Languages, Education and Communities in China. Hampshire: Palgrave Macmillan.

Valdés, Guadalupe. 2001. Learning and not Learning English: Latino Students in American Schools. New York: Teachers College Press.

Voloshinov, Valentin V, and Mikhail Bakhtin. 1973. Marxism and the philosophy of language. NY: Seminar Press.

Wang, Yang Xia. 2013. Language, Culture, and Identity among Minority Students in China: The Case of the Hui. NY: Routledge.

Weatherford, John. 2004. Genghis Khan and the Making of the Modern World. New York: Three Rivers Press.

Williams, Dee Mack. 2002. Beyond Great Walls: Environment, Identity and Development on Chinese Grasslands of Inner Mongolia. Stanford: Stanford University Press.

Willis, Paul E. 1977. Learning to labour: How working class kids get working class jobs. Columbia University Press. NY: NY. Wolcott, Harry. 1999. Ethnography: A Way of Seeing. Lanham: AltaMira Press. 